\title{
ANALISIS DISPARITAS PENDAPATAN ANTAR KABUPATEN/KOTA DI JAWA TIMUR TAHUN 2008-2013
}

\author{
LAILATUL KHUSNAH \\ Fakultas Ekonomi dan Bisnis Universitas Muhammadiyah Malang \\ e-mail : layla.khusna@gmail.com
}

\begin{abstract}
This goals is finding out the level of income disparity among districts / cities in East Java, the determine the influence of the General Allocation Fund, Gross Domestic Product and educated workforce to income disparities among districts / cities in East Java and proving the hypothesis kuznets in EAST java.The analysis technique used is Entropy Theil, multiple linear regression by the method of Random Effects Model (REM) and trend analysis of the economic growth in East Java income disparity as proof Kuznets hypothesis. Research study shows that determinant coefficient $\left(\mathrm{R}^{2}\right)$ is $(0,974)$, means thet $(97,4 \%)$, which is income disparities variabel influenced by independent variabel General Allocation Fund (DAU) (X1), Gross Regional Domestic Product (PDRB) (X2) and Educated Workforcelabour (TKTDD) (X3). The results showed the average income disparity districts / cities in East Java is high.
\end{abstract}

Keywords: Disparities in income, entropy index theil, General Allocation Fund, GDP, multiple linear regression, panel data.

\begin{abstract}
Abstrak
Penelitian ini bertujuan untuk mengetahui tingkat disparitas pendapatan antar Kabupaten/Kota di Jawa Timur, kemudian mengetahui pengaruh Dana Alokasi Umum, Produk Domestik Regional Bruto dan tenaga kerja terdidik terhadap disparitas pendapatan antar Kabupaten/Kota di Jawa Timur dan pembuktian hipotesis kuznets di Jawa Timur. Teknik analisis yang digunakan adalah Indeks Entropy Theil untuk mengukur disparitas pendapatan,Regresi linear berganda dengan metode Random Effects Model (REM), analisis Trend pertumbuhan ekonomi terhadap disparitas pendapatan di Jawa Timur sebagai pembuktian hipotesis kuznet. Hasil penelitian menunjukan disparitas pendapatan rata-rata kabupaten/kota di Jawa Timur adalah tinggi. Secara simultan variabel DAU, PDRB dan Tenaga Kerja Terdidik signifikan terhadap disparitas pendapatan antar Kabupaten/Kota di Jawa Timur pada tahun 2008-2013. Hipotesis Kuznets tentang kurva U terbalik terbukti di Jawa Timur.
\end{abstract}

Kata Kunci: Disparitas pendapatan, indeks entropy theil, Dana Alokasi Umum, PDRB, regresi linear berganda, data panel. 


\section{PENDAHULUAN}

Kuncoro (2014:203) dalam
studi empiris, ada dua jenis
ketimpangan yang menjadi pusat
perhatian. Pertama, ketimpangan
distribusi pendapatan antar golongan
pendapatan masyarakat, yang diukur
dengan indeks gini dan berapa kue
nasional yang dinikmati oleh $40 \%$
golongan pendapatan terendah.

Ketimpangan yang meningkat diukur dengan ketimpangan distribusi pendapatan yang makin lebar, sebagaimana tercermin dari rasio gini yang meningkat dari 0,33 pada tahun 2002 menjadi 0,41 pada tahun 2011, dan tetap tidak berubah hingga tahun 2013. Ironisnya, penurunan kue nasional yang dinikmati oleh $40 \%$ penduduk termiskin justru diikuti oleh kenaikan kue nasional yang dinikmati oleh 20\% kelompok terkaya dari 42,2\% tahun 2002 menjadi 49,04\% tahun 2013. Kedua, ketimpangan antardaerah penting untuk diteliti karena gravitasi aktivitas ekonomi Indonesia masih cenderung terkonsentrasi secara geografis ke Kawasan Barat Indonesia (KBI) selama lebih dari 5 dasawarsa terakhir.
Dari dimensi spasial, pulau Jawa dan Sumatra masih menjadi penyumbang terbesar Indonesia. Sumbangan aktivitas ekonomi di Pulau Jawa dan Sumatra mencapai sekitar 80\% terhadap PDB Indonesia. Artinya, kawasan timur Indonesia hanya menyumbang sekitar $20 \%$ terhadap ekonomi Indonesia. Masalnya, terjadi trend ketimpangan antarprovinsi dan kabupaten/ kota yang cenderung meningkat pacsa otonomi daerah 2001. PDRB per kapita yang tinggi terpusat pada daerah provinsi yang kaya sumberdaya alam serta daerah yang padat penduduk. Berikut ini tabel 1.1 memperlihatkan Peranan Pulau dalam pembentukan PDB Nasional (\%), 2012-2014.

Pulau Jawa menyandang ranking pertama dalam kontribusi PDB Nasional selama tahun 2012-2013. Menurut Badan Pusat Statistik (BPS), laju pertumbuhan Indonesia tahun 2011 mencapai 6,5 persen dengan nilai Produk Domestik Bruto (PDB) Rp.7.427 triliun. Pulau Jawa tetap menguasai 57,6 persen dengan tiga penyumbang terbesar yaitu DKI 
Jakarta (16,5\%), Jawa Timur (14,7\%), dibanding nasional yaitu 7,22 persen dan Jawa Barat (14,3\%). Khususnya pada 2011.

pertumbuhan yang lebih tinggi

Propinsi Jawa Timur mencatat

Tabel 1. Peranan Pulau dalam Pembentukan PDB Nasional (\%)

Tahun 2012-2014.

\begin{tabular}{lrrrr}
\hline \multirow{2}{*}{ Wilayah } & 2012 & 2013 & \multicolumn{2}{c}{2014} \\
\cline { 4 - 5 } & & & triw I & triw II \\
\hline Sumatera & 23,74 & 23,81 & 23,88 & 23,83 \\
\hline Jawa & 57,65 & 57,99 & 57,86 & 57,78 \\
\hline Bali dan Nusa Tenggara & 2,51 & 2,53 & 2,49 & 2,54 \\
\hline Kalimantan & 9,3 & 8,67 & 8,93 & 8,52 \\
\hline Sulawesi & 4,74 & 4,82 & 4,71 & 4,9 \\
\hline Maluku dan Papua & 2,06 & 2,18 & 2,13 & 2,43 \\
\hline Total & 100 & 100 & 100 & 100 \\
\hline Sumber : Badan
\end{tabular}

Sumber : Badan Pusat Statistik Indonesia, 2013

Data Badan Pusat Statistik Jawa

Timur menyebutkan pada tahun 2011 mencapai 7,22\%. Lebih tinggi dari pertumbuhan ekonomi nasional yang mencapai 6,5\%. Selain itu posisi Pendapatan Regional Bruto (PDRB) Jawa Timur yang berhasil menyentuh di level Rp428,72 triliun.

\section{Gambar 1. Pertumbuhan Ekonomi Jawa Timur dan Nasional 2008-2013}

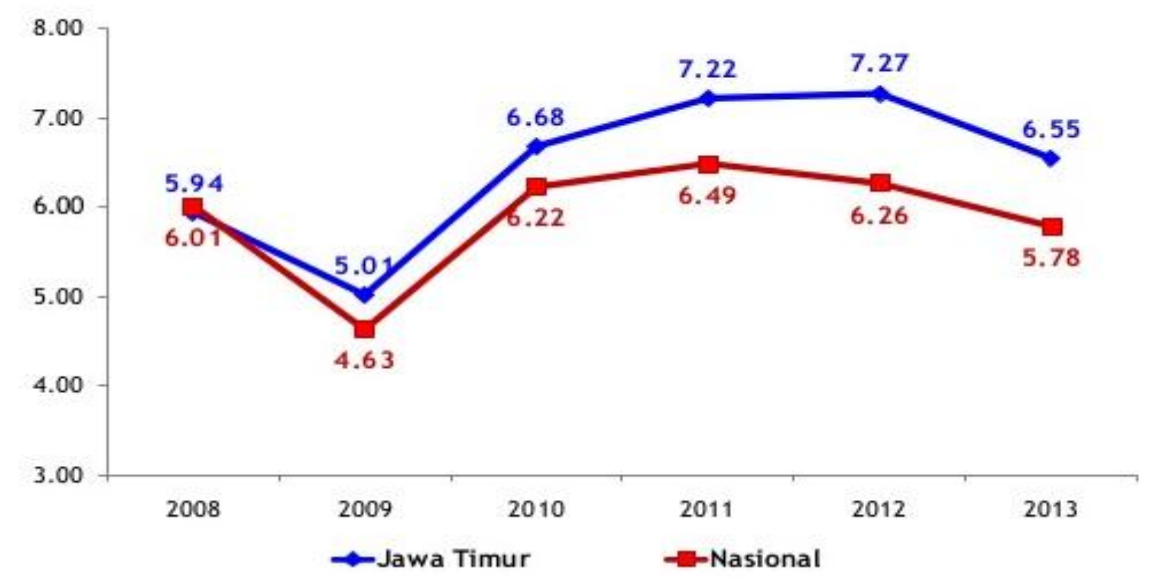

Sumber: World Bank, Diagnosa pertumbuhan ekonomi Jawa Timur, 2013 
Jawa Timur dengan Ranking pertumbuhan ekonomi yang melebihi pertumbuhan ekonomi Nasional, ternyata didalamnya terdapat raport merah yaitu terjadi kesenjangan pendapatan yang cukup tajam antar wilayah. Hal ini bisa dilihat dari kontribusi pendapatan regional tiap kabupaten/kota yang tampak pada grafik dibawah ini. Grafik yang menggambarkan kesenjangan yang tajam pada PDRB perkapita antar kabupaten/kota di Jawa Timur.

Todaro (2000) dalam Kuncoro (2004:127) Tujuan utama dari usahausaha pembangunan ekonomi selain menciptakan pertumbuhan yang setinggi-tingginya, harus pula menghapus atau mengurangi tingkat kemiskinan, ketimpangan pendapatan, dan tingkat pengangguran. Kesempatan kerja bagi penduduk atau masyarakat akan memberikan pendapatan untuk

Menurut Kuznets (dalam Kuncoro, 2006:125) seorang ekonom Klasik menyatakan bahwa pertumbuhan ekonomi di negara miskin pada awalnya cenderung menyebabkan tingginya tingkat kemiskinan dan ketidakmerataan distribusi pendapatan. Namun bila negara-negara miskin tersebut sudah semakin maju, maka persoalan kemiskinan dan ketimpangan distribusi pendapatan akan menurun (an inverse $U$ shaped patern). Beberapa ekonom pembangunan tetap berpendapat bahwa tahapan peningkatan dan kemudian penurunan ketimpangan pendapatan yang dikemukakan Kuznets tidak dapat dihindari. Berikut ini adalah gambar tentang hipotesis Kuznets.

Berdasarkan latar belakang tersebut, maka dapat dirumuskan beberapa masalah sebagai berikut:

1. Seberapa besar tingkat Disparitas pendapatan antar kabupaten/kota di Jawa Timur tahun 2008-2013?

2. Apakah Hipotesis Kuznets berlaku di Provinsi Jawa Timur?

3. Bagaimana pengaruh DAU, PDRB dan Tingkat pendidikan tenaga kerja terhadap Disparitas kabupaten/Kota di Jawa Timur?

Tujuan dalam penelitian ini adalah Untuk menganalisis seberapa besar tingkat disparitas pendapatan antar wilayah di provinsi Jawa Timur. 
Untuk menguji hipotesis kusnetz tentang kurva U terbalik apakah berlaku di Provinsi Jawa Timur. Untuk menganalisis faktor-faktor apa yang memepengaruhi disparitas pendapatan di provinsi Jawa Timur.

\section{METODE PENELITIAN}

Penelitian ini menyangkup kabupaten/ kota di Provinsi Jawa Timur. dengan objek penelitian yaitu analisis besarnya disparitas pendapatan antar kabupaten/kota, pengujian hipotesis Kuznets dan faktor-faktor yang mempengaruhi disparitas pendapatan antar kabupaten/kota dengan 3 variabel yang digunakan yaitu PDRB, Dana Alokasi Umum dan penduduk bekerja lulusan SMA. Pertimbangan dalam penentuan penelitian di Jawa Timur, dikarenakan provinsi Jawa Timur dengan ranking pertumbuhan ekonomi yang melebihi rata-rata pertumbuhan ekonomi nasional terdapat permasalahan yaitu terjadi kesenjangan yang sangat ketara dalam distribusi pendapatan antar kabupaten/kota, sehingga peneliti tertarik untuk lebih lanjut meneliti di Provinsi tersebut.
Jenis penelitian dalam penelitian ini adalah penelitian deskriptif kuantitatif, alat analisis data yang digunakan berupa statistik deskriptif. Peneliti menjelaskan fakta tersebut dengan menggunakan hasil olahan data berupa persentase, rata-rata, kecenderungan (trend), pembuktian hipotesis seorang ahli dan uji pengaruh antar variabel. Metode penelitian menggunakan regresi linier berganda dan Analisis Trend \& Analisis Korelasi

\section{PEMBAHASAN}

Jawa Timur merupakan sebuah propinsi di bagian timur Pulau Jawa, Indonesia dengan ibu kota Surabaya. Propinsi Jawa Timur memiliki 229 pulau dengan luas wilayah daratan 47.130,15 Km2 dan lautan seluas 110.764,28 Km2. Wilayah ini membentang antara $11100^{\prime} \mathrm{BT}-114^{\circ}$ 4' BT dan $7^{\circ} 12^{\prime} \mathrm{LS}-8^{\circ} 48^{\prime} \mathrm{LS}$. Sisi utara Jawa Timur berbatasan dengan Laut Jawa, sebelah selatan dengan Samudera Indonesia, sebelah timur dengan Selat Bali/Provinsi Bali dan sebelah barat dengan Provinsi Jawa Tengah. 
Secara administratif Provinsi Jawa Timur dibagi atas 38 Kabupaten dan Kota yang meliputi:

a) 29 Kabupaten terdiri dari Pacitan,

Ponorogo,

Trenggalek,

Tulungagung, Blitar, Kediri,

Malang, Lumajang, Jember,

Banyuwangi, Bondowoso,

Situbondo, Probolinggo, Pasuruan,

Sidoarjo, Mojokerto, Jombang,

Nganjuk, Madiun, Magetan, Ngawi,

Bojonegoro, Tuban, Lamongan,

Gresik, Bangkalan, Sampang,

Pamekasan dan Sumenep.

b) 9 Kota yaitu Surabaya, Madiun,

Kediri, Blitar, Malang, Batu,

Pasuruan, Probolinggo dan

Mojokerto.

\section{Analisis Disparitas Pendapatan di} Jawa Timur

Pertumbuhan ekonomi yang tinggi di Jawa Timur ternyata masih memiliki tugas besar dalam persoalan distribusi pendapatan reginal. Indeks E. Theil mampu menujukkan tingkat disparitas pendapatan di Jawa Timur dan Kab/Kota selama periode penelitian. Tinggi rendahnya indeks dipengaruhi oleh disparitas PDRB per kapita. Semakin timpang pertumbuhan PDRB per kapita semakin tinggi Indeks E. Theil dan disparitas pendapatan. Gambar 4.3 indeks disparitas entropy theil dan pertumbuhan ekonomi Jawa Timur dan tabel 4.3 menunjukan besarnya IET dan pertumbuhan ekonomi Jawa Timur selama tahun 2008-2013.

\section{Gambar 2. Indeks Entropy Theil dan Pertumbuhan Ekonomi Jawa Timur}

Tahun 2008-2013.

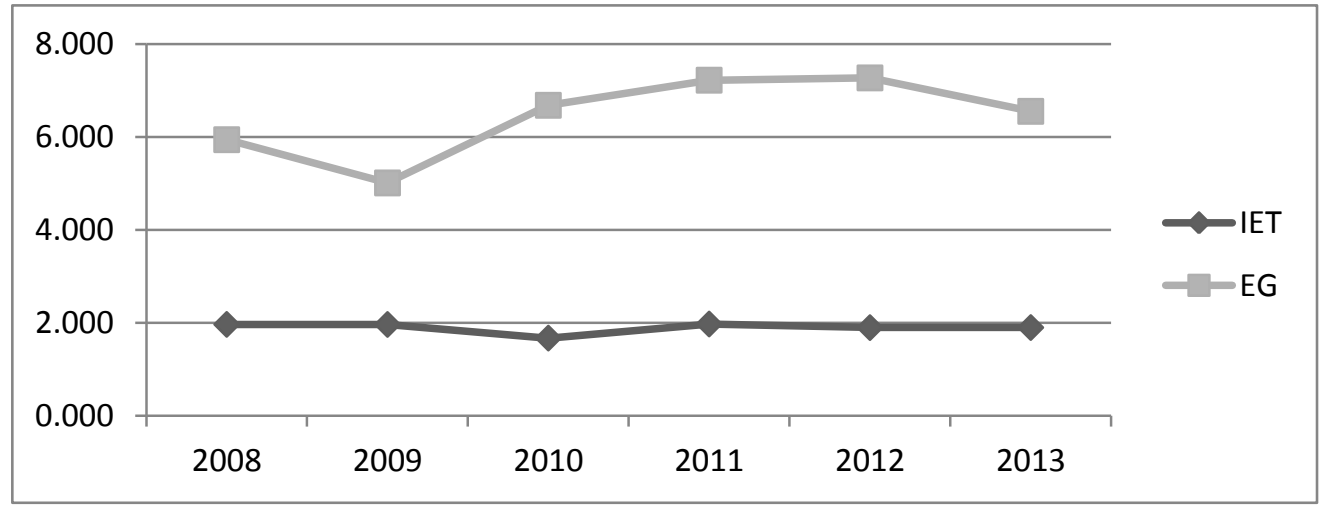

Sumber : Data diolah, 2015 
Pada gambar 2. mengalami peningkatan sebesar 0,304 memperlihatkan tingkat disparitas menjadi 1.975 pada 2011. Kondisi pendapatan di Jawa Timur dengan disparitas pendapatan di Jawa Timur menggunakan indeks E. Theils yang sangat fluktuatif sejak tahun 2008tergolong tinggi. Nilai rata-rata indeks 2013.

Entropy Theil di Jawa Timur sebesar 1.967 (2008), 1.965 (2009), 1.671 (2010), 1.975 (2011), 1.897 (2012), 1.899 (2013). Indeks E. Theil menurun sebesar 0,294 dari 1.965 pada 2009 menjadi 1.671 pada 2010, namun

\section{Tabel 2. Pembagian kabupaten/kota dalam Indeks Entropy Theil Jawa Timur Tahun 2008 - 2013.}

\begin{tabular}{cl} 
Keterangan & \multicolumn{1}{c}{ Kabupaten/kota } \\
\hline $\begin{array}{c}\text { Disparitas } \\
\text { Pendapatan } \\
(0<\mathrm{IET}<0,4)\end{array}$ & Kab.Pamekasan \\
\hline Disparitas & \\
Pendapatan & Kab.Pacitan, Kab.Bangkalan, Kab.Sampang. \\
$(0,4<\mathrm{IET}<0,5)$ & Kab. Ponorogo, Kab. Trenggalek, Kab. Tulung Agung, Kab. \\
\hline Disparitas \\
pendapatan \\
Blitar, Kab. Kediri, Kab. Malang, Kab. Lumajang, Kab. \\
Jember, Kab. Banyuwangi, Kab. Bondowoso, Kab. Sitibondo, \\
Kab. Probolinggo, Kab. Pasuruan, Kab. Sidoarjo, Kab. \\
Mojokerto, Kab. Jombang, Kab.Nganjuk, Kab.Madiun, \\
Kab.Magetan, Kab.Ngawi, Kab.Bojonegoro, Kab.Tuban, \\
Kab.Lamongan, Kab.Gresik, Kab.Sumenep, Kota Kediri, \\
Kota Blitar, Kota Malang, Kota Probolinggo, Kota Pasuruan, \\
Kota Mojokerto, Kota Madiun, Kota Surabaya, Kota Batu.
\end{tabular}

Sumber : data diolah, 2015. 
Berdasarkan rata-rata tingkat disparitas dari tahun 2008 sampai 2013 hanya ada satu daerah yang memiliki indeks disparitas pendapatan rendah yaitu kabupaten Pamekasan. Jawa Timur memiliki rata-rata indeks disparitas pendapatan yang tinggi sebesar 1,8957. Terdapat 9 kota dan 25 kabupaten dengan disparitas pendapatan tinggi dan 3 kabupaten dengan indeks disparitas pendapatan yang sedang dan hanya satu kabupaten dengan angka indeks disparitas pendapatan yang rendah.

Kota Kediri memiliki tingkat disparitas terbesar yaitu 27.248 (2008), 27.130 (2009), 18.429 (2010), 27.937 (2011), 26.890 (2012), 26.788 (2013). Dalam rentang waktu 2008 sampai 2013 Indeks E. Theil di Kota Kediri terendah pada tahun 2010 kemudian 2013, namun masih sangat tinggi jika dibandingkan dengan rata-rata di Jawa Timur. Hal ini dipengaruhi oleh dari nilai PDRB per kapita yang sangat besar dengan hadirnya perusahaan rokok PT. Gudang Garam yang berskala nasional. Meskipun memiliki PDRB per kapita tertinggi di Jawa Timur, Kota Kediri memilki laju pertumbuhan 5,37 persen dibawah rata-rata Jawa Timur yang sebesar 6,55 persen.

\section{Pengujian Hipotesis Kuznets tentang kurva $U$ terbalik.}

Hipotesis Kuznet menunjukkan hubungan antara pertumbuhan ekonomi (PDRB) dengan tingkat disparitas pendapatan (Indeks E. Theil). Pembuktian hipotesis Kuznet dilakukan dengan membuat grafik yang menjelaskan hubungan antara Indeks E. Theil dengan laju pertumbuhan ekonomi.

Berikut grafik yang memperlihatkan hubungan pertumbuhan dan tingkat disparitas: 


\section{Gambar 2. Hubungan Diparitas pendapatan dengan} pertumbuhan ekonomi Jawa Timur.

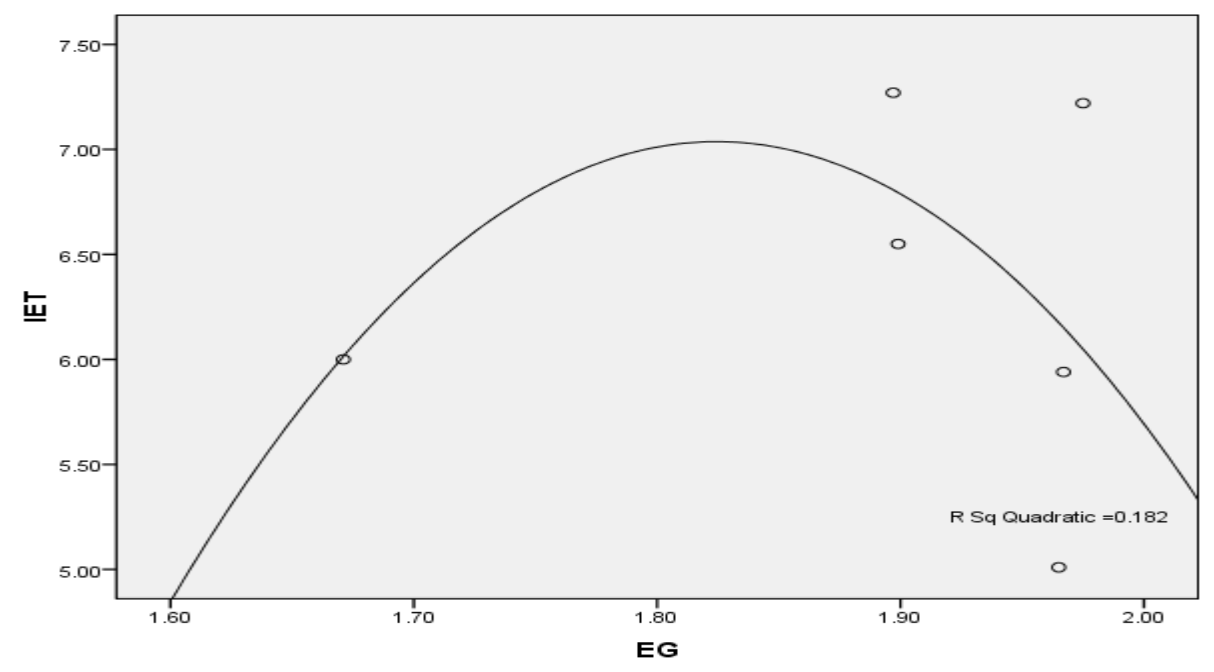

Sumber : data diolah, 2015.

\begin{abstract}
Disparitas pendapatan suatu daerah mengalami kenaikan pada periode tertentu kemudian turun ketika pertumbuhan semakin meningkat dan akhirnya meningkat lagi sehingga menjadi proses yang berulang. Penelitian di Jawa Timur Hal ini sama pula seperti penelitian sudantoko dan kuncoro pada tahun 2013 di kabupaten
\end{abstract} Banyumas yang menunjukan pembuktian kurva U terbalik.

Dalam Sjafrizal (2008: 97-98) Hipotesis Kuznet disebut juga hipotesis kurva $U$ terbalik (inverted $U$ curve) yang menjelaskan : a) Adanya relasi antara ketimpangan dan tingkat pendapatan per kapita dalam bentuk kurva $\mathrm{U}$ terbalik.

b) Pada tahap awal pembangunan, ketimpangan cenderung meningkat akibat kemajuan teknologi, peningkatan investasi dan jumlah tenaga kerja yang berhubungan positif dangan pertumbuhan ekonomi.

c) Pada tahap akhir pembangunan, setelah mencapai titik maksimum bila pembangunan terus dilanjutkan maka ketimpangan antar daerah akan berkurang.

Selanjutnya, hasil analis korelasi Pearson antara pertumbuhan 
ekonomi dan Indeks Entropy Theil tersaji pada tabel dibawah ini:

Tabel 4. Korelasi Person Indeks Entropy Theil dan Pertumbuhan Ekonomi.

\begin{tabular}{|c|c|c|c|}
\hline & & $\begin{array}{l}\text { Econo } \\
\text { mic } \\
\text { Growth }\end{array}$ & $\begin{array}{l}\text { Indeks } \\
\text { Entropy } \\
\text { Theil }\end{array}$ \\
\hline \multirow{4}{*}{$\begin{array}{l}\text { Economic } \\
\text { Growth }\end{array}$} & Pearson & & \\
\hline & $\begin{array}{l}\text { Correlati } \\
\text { on }\end{array}$ & 1 & .055 \\
\hline & $\begin{array}{l}\text { Sig. } \\
\text { (1-tailed) }\end{array}$ & & .459 \\
\hline & $\mathrm{N}$ & 6 & 6 \\
\hline \multirow{4}{*}{$\begin{array}{l}\text { Indeks } \\
\text { Entropy } \\
\text { Theil }\end{array}$} & Pearson & & \\
\hline & $\begin{array}{l}\text { Correlati } \\
\text { on }\end{array}$ & .055 & 1 \\
\hline & $\begin{array}{l}\text { Sig. } \\
\text { (1-tailed) }\end{array}$ & 459 & \\
\hline & $\mathrm{N}$ & 6 & 6 \\
\hline
\end{tabular}

Sumber : Data Diolah, 2015

Hasil analis korelasi Pearson antara pertumbuhan ekonomi dan Indeks Entropy Theil mendapatkan nilai sebesar 0,055. Angka 0,055 menunjukkan koefisien korelasi Pearson memiliki hubungan yang lemah. Hal ini karena, Koefisien korelasi hanya dapat menggambarkan keeratan hubungan yang bersifat linier dan tidak mampu menggambarkan hubungan yang bersifat non linier. Bisa kita lihat pada analisis trend pembuktian Hipotesisi Kuznets yang berbentuk kurva $U$ terbalik, hal ini menunjukkan kedua variabel memiliki hubungan positif kemudian sampai titik tertentu memiliki hubungan negatif, maka jelas jika hasil koefisien korelasinya mendekati angka 0 atau korelasinya lemah. Tetapi hal ini tidak berarti bahwa kedua variabel tersebut saling independen, walau tidak menutup kemungkinan kedua variabel memiliki hubungan kausalitas yang bersifat non-linier.

Hasil output diatas menunjukkan Hasil korelasi ini tidak kuat secara statistik karena nilai signifikansi $0,459 \%>\alpha=5 \%$. Namun nilai positif sesuai dengan grafik yang menujukkan hubungan positif antara pertumbuhan dengan Indeks Entropy Theil. Hubungan yang positif menunjukkan hubungan searah yaitu kenaikan pertumbuhan ekonomi diikuti oleh pertumbuhan disparitas pendapatan (indeks Entropy Theil).

\section{Hasil analisis regresi dan} pembahasan

1. Pemilihan Teknik Estimasi Regresi Data Panel

a) Uji Statistik $\mathbf{F}$

Uji statistik F untuk mengetahui signifikansi teknik Fixed Effect. Kegunaan uji $\mathrm{F}$ statistik yaitu untuk 
memilih antara metode OLS (Common Effect) tanpa variabel dummy atau metode Fixed Effect.

Diketahui:

$$
\begin{aligned}
\text { RSS1 } & =1945.536 \\
\text { RSS2 } & =71.42010 \\
\mathrm{~m} & =38-1=37 \\
\mathrm{n} & =38 \times 6=228 \\
\mathrm{k} & =3
\end{aligned}
$$

Maka uji F statistik dapat dihitung dengan rumus :

$$
\begin{gathered}
\mathrm{F}=\frac{\left(\mathrm{RSS}_{1}-\mathrm{RSS}_{2}\right) / \mathrm{m}}{\left(\mathrm{RSS}_{2}\right) /(\mathrm{n}-\mathrm{k})} \\
\mathrm{F}=\frac{(1945.536-71.42010) / 37}{(71.42010) /(228-3)} \\
\mathrm{F}=\frac{50.65178}{0.31742} \\
\mathrm{~F}=159.57337
\end{gathered}
$$

Numerator $=159$ dan denumerator $=228-3-1=224$, pada $\alpha=5 \%(0.05)$ diperoleh nilai $\mathrm{F}$ tabel $=$ 1.29 dan dari uji $\mathrm{F}$ diperoleh nilai $\mathrm{F}$ hitung sebesar 31.2472. Jadi nilai F hitung (31.2472) $\geq F$ tabel (1.29). Maka dapat disimpulkan bahwa $\mathrm{H}_{0}$ ditolak dan Ha diterima, berarti model Fixed Effect merupakan model yang tepat.

b) Uji Lagrange Multiplier (LM)

Uji Lagrange Multiplier (LM) digunakan untuk mengetahui apakah model
Random Effect lebih baik dari metode OLS (Common Effect). Nilai statistik Lagrange Multiplier (LM) dihitung berdasarkan rumus sebagai berikut:

Diketahui:

$$
\begin{aligned}
& \mathrm{n} \quad=228 \\
& \mathrm{~T} \quad=6 \\
& \mathrm{Df} \quad=\mathrm{n}-1=221 \\
& \mathrm{E} \quad=1945.536 \\
& \mathrm{LM}=\frac{n T}{2(T-1)}\left[\frac{\sum_{i=1}^{i}\left[\sum_{t=1}^{T} e_{i t}\right]}{\sum_{i=1}^{n} \sum_{t=1}^{T} e_{i t}^{2}}-1\right]^{2} \\
& \mathrm{LM}=\frac{n T}{2(T-1)}\left[\frac{\sum_{i=1}^{n}(T e)^{2}}{\sum_{i=1}^{n} \sum_{t=1}^{T} e_{i t}^{2}}-1\right] 2 \\
& \mathrm{LM}=\frac{228 x 6}{2[6-1]}\left[\frac{1945.536^{2}}{1945.536}-1\right]^{2} \\
& \mathrm{LM}=136.8(1945.536-1)^{2} \\
& \mathrm{LM}=136.8(3785109.31) \\
& \mathrm{LM}=517802953.608
\end{aligned}
$$

Nilai df sebesar $(n-1)=228-$ $1=227$ pada $\alpha=5 \%$ (0.05) diperoleh nilai $\chi^{2}$ tabel sebesar 264.224. Jadi nilai LM hitung (504176562.39502) $\geq$ $\chi^{2}$ tabel (264.224), maka dapat disimpulkan bahwa $\mathrm{H}_{0}$ ditolak dan $\mathrm{H}_{\mathrm{a}}$ diterima, berarti bahwa model Random Effect adalah model yang tepat.

\section{c) Uji Hausman}

Hasil uji signifikansi dengan menggunakan uji $\mathrm{F}$ dan uji Lagrange Multiplier (LM) diperoleh hasil bahwa 
teknik yang paling tepat adalah Fixed Effect dan Random Effect. Untuk memilih antara teknik Fixed Effect dan Random Effect, maka diuji kembali dengan uji Hausman.

Uji Hausman ini sangat kompleks sehingga untuk menghitungnya digunakan alat bantu progam eviews 4 . Hasil uji dari Hausman adalah sebagai berikut :

$$
m=\hat{q} \operatorname{Var}(\hat{q})^{-1} \hat{q}=3.730146
$$

Nilai df sebesar $(\mathrm{n}-1)=222-1=$ 221 pada $\alpha=5 \%$ (0.05) diperoleh nilai $\chi^{2}$ tabel sebesar 256.680. Dari hasil olah data Hausman hitung yaitu sebesar 3.730146. Jadi Hausman hitung $(3.730146)<\chi^{2}$ tabel $(256.680)$. Maka dapat disimpulkan bahwa $\mathrm{H}_{0}$ diterima dan Ha ditolak, berati model Random Effect merupakan model yang paling tepat.

\section{Hasil Analisis Regresi Linier Berganda Data Panel}

Berdasarkan beberapa tahapan yang telah diuji di atas, melalui uji $F$ kemudian LM maka dapat disimpulakan bahwa dipilihlah model Random effect adalah pilihan yang tepat. Regeresi menggunakan Random effect model tepat untuk menggambarkan keanekaragaman karakteristik antar kabupaten/kota di Jawa Timur yang tentunya meiliki karakteristik berbeda-beda.

Hasil dari model persamaan regresi dapat ditulis dalam bentuk:

$$
\begin{aligned}
& \text { IET }=3.074596-2.851761 \operatorname{LogDAU} \\
& +\quad 4.248049 \operatorname{LogPDRB}-0.118280 \\
& \log \mathrm{TKTDD}+\mathbf{\epsilon t} \\
& \mathrm{T}=(0.909520) * \quad(-3.253890) \\
& \quad(3.563902) \\
& \mathrm{R}^{2}=(0.974693)
\end{aligned}
$$

Koefisien intercept/konstanta (C) 3.074596 adalah rata-rata komponen random (intersep) koefisien residual yang bersifat random dan berbeda antar daerah. Nilai intercept dan slope pada masing-masing daerah berbeda, hal tersebut menunujukkan keunikan dari model estimasi Random Effect. Hasil estimasi menunjukkan bahwa nilai random effect terendah adalah sebesar -0.2304027 (KAB SISOARJO--C) dan nilai tertinggi 20.5447 (KOTA KEDIRI--C). Hal ini berarti besarnya perbedaan intersep antara KAB SIDOARJO -0.2304027 dan KOTA KEDIRI 20.5447. Dari sini bisa dihitung besarnya intersep untuk KAB SIDOARJO yaitu sebesar 
$3.074596-0.2304027=2.84419$ dan intersep KOTA KEDIRI sebesar $3.074596+20.5447=23.61929$.

Dari tabel 4.5 terlihat bahwa tiga nilai intersep tertingi adalah Kota Kediri (20.5447), Kota Mojokerto (2.593909), Kota Madiun (2.299338). Sedangkan, tiga ranking intercept terendah adalah kab Jember (-2.046508), Kabupaten Malang (2.303553), Kab Sidoarjo (-2.304027).

\section{Hasil Uji Signifikansi Simultan} (Uji Statistik F) dan Uji Parsial (uji statistik-t)

Uji hipotesis dilakukan untuk mengetahui ada tidaknya pengaruh secara simultan dan parsial hubungan variabel bebas terhadap variabel terikat. Pengujian hipotesis ada dua macam yaitu uji simultas (Uji F), uji parsial (Uji t), dan uji determinan $\left(R^{2}\right)$.

a) Uji F (simultan)

Uji F merupakan metode pengujian untuk mengetahui ada tidaknya pengaruh secara simultan (serentak) antara seluruh variabel bebas (Pajak Daerah (X1), Belanja Pemerintah (X2), dan PDRB Perkapita (X3)), terhadap variabel terikat (Indeks Persepi
Korupsi). Niali F hitung dapat dihitung dengan rumus

$$
F=\frac{R^{2} / k}{\left(1-R^{2}\right) /(n-k-1)}
$$

Keterangan :

$\mathrm{F} \quad=$ Rasio koefisien penentu

$R^{2} \quad=$ Koefisien determinan

$\mathrm{N} \quad=$ Jumlah observasi

$\mathrm{K}=$ Jumlah parameter termasuk intercept/konstan (variabel bebas)

Diketahui:

$$
\begin{aligned}
R^{2} & =0.974693 \\
\mathrm{n} & =228 \\
\mathrm{k} & =3
\end{aligned}
$$

jadi, nilai $F_{\text {hitung }}$ dapat dihitung dengan cara:

$$
\begin{gathered}
F=\frac{R^{2} / k}{\left(1-R^{2}\right) /(n-k-1)} \\
F=\frac{0.974693 / 3}{(1-0.974693) /(228-3-1)} \\
F=\frac{0.974693 / 3}{0.02531 / 224} \\
F=\frac{0.3249}{0.00011} \\
F=2963,63636
\end{gathered}
$$

Nilai $d f_{1}$ sebesar 3 , dan $d f_{2}=\mathrm{n}-\mathrm{k}-$ $1=228-3-1=224$ atau df $(3,224)$ pada $\alpha=5 \%(0,05)$ diperoleh nilai $F_{\text {tabel }}$ sebesar 2,6476. Nilai $F_{\text {hitung }}>F_{\text {tabel }}(2963,63636>2,6476$ ). Maka dapat di ambil kesimpulan 
bahwa $H_{0}$ ditolak dan $H_{a}$ diterima. Dengan demikian menunjukan bahwa variabel independen yaitu Dana Alokasi Umum (X1), Produk domestic regional Bruto(X2), dan Tenaga kerja terdidik (X3) secara bersama-sama mempunyai pengaruh signifikan terhadap variabel dependen (Indeks Entropi Theil).

\section{a. Uji t (parsial)}

Uji $\mathrm{t}$ merupakan uji untuk mengetahui ada tidaknya pengaruh secara parsial (individu) antara masing-masing variabel independent (DAU, PDRB dan TKTDD). Terhadap varaibel dependent (Indeks Entropy Theil). Jika $t_{\text {hitung }}<t_{\text {tabel }}$ maka Ho diterima dan Ha ditolak, berarti tidak ada pengaruh antara variabel independent terhadap variabel dependent adalah tidak signifikan. Maka dari hasil estimasi regresi data panel dapat di ketahui nilai $t_{\text {hitung }}$ dan probabilitas masing-masing variabel bebas. Hasil estimasi tersebut disajikan pada table dibawah ini.

Tabel 5. Hasil uji (t) parsial

\begin{tabular}{ccccc}
\hline variabel & Coef & Std eror & t-statistc & prob \\
\hline C & 3.074596 & 3.38046 & 0.90952 & 0.3641 \\
\hline Log DAU & -2.851761 & 0.87641 & -3.25389 & 0.001 \\
\hline Log PDRB & 4.248049 & 4.24804 & 3.563902 & 0.004 \\
\hline Log TKTDD & -0.118280 & 0.38482 & -0.30736 & 0.758 \\
\hline
\end{tabular}

Sumber : eviews 4, diolah 2015

Berdasarkan hasil estimasi diatas, maka berikut ini dapat dijelaskan pengujian pengaruh signifikansi masing-masing variabel independent (DAU, PDRB dan TKTDD) terhadap variabel dependent (Indeks Entropy Theil) yaitu sebagai berikut:

\section{Dana Alokasi Umum (X1)}

Kuncoro (2004) Dana Alokasi Umum adalah merupakan transfer yang bersifat umum (block grant) yang diberikan kepada semua kabupaten dan kota untuk tujuan mengisi kesenjangan antara kapasitas dan kebutuhan fiskalnya dan didistribusikan dengan formula berdasarkan prinsip-pinsip 
tertentu yang secara umum mengindikasikan bahwa daerah miskin dan terbelakang harus menerima lebih banyak dari pada daerah kaya.

Variabel DAU daerah memiliki nilai $t_{\text {hitung }}$ sebesar -3.253890 sdan nilai probabilitas sebesar 0.0013 hal ini menunjukan bahwa nilai $t_{\text {hitung }}$ sebesar $-3.253890<(1,9592)$ dan nilai probabilitas $(0.0013)<\alpha=5 \%$. Maka Ho ditolak dan Ha diterima, dengan demikian dapat disimpulkan bahwa variabel Dana alokasi Umum (X1) secara parsial berpengaruh negatif tidak signifikan terhadap kesenjangan pendapatan (Y) dan probabilitas sebesar 0.0013 lebih kecil dari tingkat kesalahan 5\% maka hasilnya signifikan.

\section{Produk Domestik Regional Bruto} (X2)

Variabel Produk Domestik Regional Bruto (X2) memiliki nilai $t_{\text {hitung }}$ sebesar 3.253890 dan nilai probabbilitas sebesar 0.0004. hal ini menunjukan nilai $t_{\text {hitung }}$ sebesar $3.253890>t_{\text {tabel }}(1,9592)$ dan nilai probabalitas $(0.0004)>\alpha=5 \%$. Maka Ho ditolak dan Ha diterima, dengan demikian dapat disimpulkan bahwa variabel Produk Domestik Regional Bruto (X2) secara parsial berpengaruh signifikan terhadap kesenjangan pendapatan $(\mathrm{Y})$.

Hasil penelitian ini sama seperti penelitian Forbes dalam Waluyo (2004:7) dan hipotesis Kuznet yang menyatakan bahwa dalam jangka pendek hubungan antara disparitas pendapatan dengan pertumbuhan ekonomi adalah positif dan signifikan. Pada awal proses pembangunan, pertumbuhan yang tinggi di negara berkembang menyebabkan tingkat perbedaan kemakmuran antar daerah menjadi tinggi (divergence) seperti terlihat di Propinsi Jawa Timur.

\section{Tenaga kerja Terdidik (X3)}

Tenaga kerja terdidik (X3) memiliki nilai $t_{\text {hitung sebesar - }}$ 0.307365 dan nilai probabilitas sebesar 0.7589. hal ini menunjukan nilai $t_{\text {hitung }}(-0.307365)<t_{\text {tabel }}(1,9592)$ dan nilai probabilitas $(0.7589)>\alpha=$ 5\%. Maka Ho diterima dan Ha ditolak, dengan demikian dapat disimpulkan bahwa variabel PDRB Perkapita (X3) 
secara parsial tidak berpengaruh terhadap variabel kesenjangan pendapatan (Y). dijelaskan pada gambar dibawah ini:

Koefisien determinasi

digunakan untuk mengetahui besarnya (persen) perubahan variasi-variabel dependen mampu dijelaskan oleh variasi variabel independen. Nilai R2 berkisar antara 0 (nol) dan 1 (satu), semakin mendekati 1 berarti model penelitian makin baik. Dari hasil estimasi diperoleh nilai R2 sebesar 0.974693 atau sebesar 97,46\% sehingga model persamaan tersebut mampu menjelaskan pengaruh DAU, PDRB, Tenaga kerja terdidik terhadap tingkat disparitas pendapatan (IET) sebesar 0.9746 atau $97,46 \%$ dan sisanya sebesar $2,54 \%$ dijelaskan oleh variabel-variabel lain diluar persamaan tersebut.

\section{Pengaruh Variabel Dana Alokasi} Umum terhadap disparitas pendapatan antar kabupaten/kota di Jawa Timur tahun 2008-2013.

Hasil uji parsial (uji t) antara variabel Dana Alokasi Umum dengan disparitas pendapatan yang diukur menggunakan indeks entropy theil menunjukan nilai $t_{\text {hitung }}$ sebesar 3.253890, koefisien -2.851761 dan nilai probabilitas sebesar 0.0013 yang lebih kecil dari nilai $\alpha 5 \%(0,05)$. Hal tersebut menunjukan bahwa variabel dana alokasi umum berpengruh signifikan negatif terhadap kesenjangan pendapatan antar kabupaten/kota di Jawa Timur selama tahun penelitian berlangsung.

Kuncoro (2004) Dana Alokasi Umum adalah merupakan transfer yang bersifat umum (block grant) yang diberikan kepada semua kabupaten dan kota untuk tujuan mengisi kesenjangan antara kapasitas dan kebutuhan fiskalnya dan didistribusikan dengan formula berdasarkan prinsip-pinsip tertentu yang secara umum mengindikasikan bahwa daerah miskin dan terbelakang harus menerima lebih banyak dari pada daerah kaya.

Dalam penelitian ini selama tahun penelitian berlangsung, Dana alokasi umum menunjukan pengaruh signifikan negatif ini berarti dana alokasi umum yang berfungsi untuk mengurangi fiscal gap antar daerah 
mulai terlihat kinerjanya. Semakin banyak dana alokasi umum yang digelontorkan untuk daerah yang kurang mampu dalam finansial untuk pemenuhan fasilitas public atau kegiatan dalam rangka mengurangi kesenjangan pembangunan suatu daerah akan mengurangi disparitas pendapatan antar daerah.

\section{Pengaruh Produk domestik}

Regional Bruto Terhadap Disparitas Pendapatan Antar Kabupaten/ Kota Di Jawa Timur Selama Tahun 2008 - 2013.

Hasil pengujian parsial (uji t) antara variabel belanja pemerintah dengan variabel terikat yaitu Kesenjangan pendapatan (IET) menunjukan nilai $t_{\text {hitung }}$ sebesar 3.563902 koefisien 4.248049 dan nilai probabilitas sebesar 0.0004 lebih kecil dari $\alpha$ 0,05. Dapat disimpulkan bahwa terdapat pengaruh siginifikan terhadap variabel dependent Indeks disparitas pendapatan pada 29 kabupaten dan 9 kota di Jawa Timur tahun 2008, 2009, 2010, 2011, 2012, 2013.

Laju pertumbuhan yang tinggi (PDRB di atas rata-rata) di Jawa Timur hanya dinikmati beberapa daerah seperti Kab. Bojonegoro, Kab. Gresik, Kota Malang, Kota Kediri Kota Surabaya dan Kab. Sidoarjo sehingga tingkat disparitas pendapatan berkorelasi positif dengan PDRB. Kondisi ini menunjukkan spread effect lebih rendah dari backwash effect sehingga jurang kesejahteraan antara daerah yang kaya dengan daerah miskin semakin melebar. Dengan kata lain pembangunan di daerah maju menimbulkan hambatan bagi daerah yang terbelakang untuk berkembang.

Jurang pembangunan dapat mengecil kembali saat daerah yang kaya sudah semakin berkembang. Kondisi tersebut menimbulkan disekonomis eksternal terhadap berbagai perusahaan dan industri, yang ditimbulkan oleh kongesti-kongesti yang terjadi di daerah yang lebih maju. Dalam jangka panjang aliran investasi dan pertumbuhan akan bergerak daerah yang belum berkembang sehingga disparitas pendapatan nantinya akan turun.

Pengaruh Tenaga Kerja Terdidik Terhadap Disparitas Pendapatan 
Hasil pengujian parsial (uji t) antara variabel TKTDD yaitu tingkat pendidikan penduduk usia 15 tahun keatas yang bekerja dengan pendidikan lulusan lebih dari SLTP atau minimal SMA/SMK sederajat dengan variabel terikat kesenjangan pendapatan (IET) menunjkan nilai $t_{\text {hitung }}-0.307365$ koefisien -0.118280 dan probabilitas 0.7589 lebih besar dari 0,05. Dapat disimpulkan bahwa adanya pengaruh tidak signifikan negatif terhadap kesenjangan pendapatan antar kabupaten/kota di Jawa Timur pada tahun penelitian berlangsung.

Berdasarkan analisis di atas menunjukan variabel TKTDD tidak berpengaruh signifikan selama tahun penelitian berlangsung 2008 - 2013 hal ini bisa disebabkan oleh tingkat pendidikan di Jawa Timur 53 persen adalah penduduk bekerja dengan pendidikan tamatan SD ke bawah. Data Badan Pusat statistik dalam statistik Daerah Provinsi Jawa Timur 2013 menunjukkan data Penduduk bekerja menurut pendidikan dengan tamatan SLTP hanya 28 persen, penduduk bekerja lulusan SMU hanya
13 persen dan SMK 9 persen kemudian tamatan perguruan tinggi sebanyak 9 persen. Sehingga, tingkat pendidikan di Jawa Timur tidak berpengaruh terhadap kesenjangan pendapatan sebab pendidikan mayoritas seragam lulusan SD sampai SD kebawah.

\section{Kesimpulan Dan Saran}

Berdasarkan analisis yang
dilakukan pada Bab sebelumya,
terdapat beberapa hal yang menjadi
kesimpulan dari penelitian ini yaitu :
Disparitas pendapatan
kabupaten/kota di Provinsi Jawa Timur
yang diukur dengan Indeks Entrophy
Theil dari tahun 2008-2013 tergolong
tinggi dengan satu daerah memiliki
indeks disparitas pendapatan kurang
dari 0.4 , tiga daerah dengan tingkat
disparitas $0.4<$ IET>0.5 dan tiga puluh
empat daerah menembus indeks di atas
0.5 hingga mencapai lebih dari indeks
disparitas rata-rata di Jawa Timur.
Penelitian ini menunjukkan
bahwa selama tahun penelitian
berlangsung secara Simultan baik
variabel DAU, PDRB dan TKTDD


signifikant terhadap Diparitas

Pendapatan. Sedangkan, secara Parsial melalui uji t-statistik variabel Produk Domestik Regional Bruto (PDRB) berpengaruh signifikan dan positif terhadap disparitas pendapatan. Dana Alokasi Umum (DAU) berpengaruh Signifikan negatif terhadap disparitas pendapatan. Sedangkan Tenaga kerja terdidik (tenaga kerja lulusan lebih dari SLTP) tidak berpengaruh signifikan terhadap disparitas pendapatan antar kabupaten/Kota. Sehingga, Kebijakan-kebijakan pemerintah dalam mengurangi disparitas dapat difokuskan kepada kedua variabel di atas tanpa mengabaikan variabel yang tidak berpengaruh signifikan.

Hipotesis Kuznet mengenai Kurva U-Terbalik terbukti di Provinsi Jawa Timur. Pada tahap awal pertumbuhan ketimpangan cenderung meningkat namun pada tahap-tahap berikutnya ketimpangan akan menurun seiring pertumbuhan. Proses ini berlangsung berulang-ulang sehingga dalam jangka panjang hubungan antara pertumbuhan ekonomi dengan disparitas pendapatan adalah negatif. Pemerintah harus terus mendorong pertumbuhan ekonomi agar pemerataan pendapatan antar daerah segera terwujud, sehingga mengurangi jurang disparitas pendapatan antar wilayah.

\section{DAFTAR PUSTAKA}

Badan Pusat Statistik (BPS). 2008 2013. Keadaan Angkatan Kerja di Propinsi Jawa Timur. Surabaya: Badan Pusat Statistik.

Badan Pusat Statistik (BPS). 2008 2013. Tinjauan Regional Berdasarkan PDRB kabupaten/kota 2009-2013. Jakarta: Badan Pusat Statistik. Kuncoro, Mudrajad. 2004.Otonomi dan pembangunan Daerah.Jakarta: Erlangga.

Kuncoro, Mudrajad. 2006. Ekonomika Pembangunan : Teori Masalah dan Kebijakan. Jakarta: Erlangga.

Kuncoro, Mudrajad. 2014. Otonomi Daerah: Menuju Erabaru 
Pembangunan Daerah Edisi

3, Jakarta, Erlangga.

Sanusi, Anwar. 2011. Metodologi

Penelitian Bisnis. Salemba Empat.

Jakarta.

Sjafrizal. 2008. Ekonomi Regional:

Teori dan Aplikasi. Padang:

Baduose Media.

Suliyanto. 2011. Ekonometrika terapan: Teori\&Aplikasi dengan sps. Yogyakarta: Andi Yogyakarta

Waluyo, Joko. 2004. Hubungan antara tingkat kesenjangan pendapatan dengan

pertumbuhan ekonomi : suatu studi lintas negara. Jurnal Ekonomi Pembangunan, Vol. 9, Hal: 1-20.

World Bank. 2013. Diagnosa Pertumbuhan Ekonomi Jawa Timur: $\quad$ Mengidentifikasi Hambatan-Hambatan Utama Pertumbuhan yang Inklusif di Provinsi Terbesar Kedua di Indonesia. Jakarta. 